\title{
Erratum to: Application of soft computing techniques for modeling and analysis of MRR and taper in laser machining process as well as weld strength and weld width in laser welding process
}

\author{
Mansour Aminian · Reza Teimouri
}

Published online: 6 January 2015

(C) Springer-Verlag Berlin Heidelberg 2015

Erratum to: Soft Comput

DOI 10.1007/s00500-014-1305-x

The two authors' names "Mohammadhosein Ghasemi Baboly" and "Zayd Leseman" in the author group were wrongly published in the original publication. The correct author group is given below:

Mansour Aminian · Reza Teimouri

The online version of the original article can be found under doi:10.1007/s00500-014-1305-x.

M. Aminian

Department of Mechanical Engineering, Faculty of Engineering,

University of Tabriz, Tabriz, Iran

R. Teimouri $(\varangle)$

Department of Mechanical Engineering,

Babol University of Technology, Babol, Iran

e-mail: reza_teimoori@yahoo.com 